\title{
Multidimensional Food Security Nexus in Drylands under the Slow Onset Effects of Climate Change
}

\author{
Ilan Stavi ${ }^{1,2, *(\mathbb{D})}$, Anastasia Paschalidou ${ }^{3}$, Apostolos P. Kyriazopoulos ${ }^{3}\left(\mathbb{D}\right.$, Rares Halbac-Cotoara-Zamfir ${ }^{4}(\mathbb{D}$, \\ Si Mokrane Siad ${ }^{5,6,7} \oplus$, Malgorzata Suska-Malawska ${ }^{8,9}$, Dragisa Savic ${ }^{10}{ }^{10}$, Joana Roque de Pinho ${ }^{11}$, \\ Lisa Thalheimer ${ }^{12}$, David Samuel Williams ${ }^{13}$, Nurit Hashimshony-Yaffe ${ }^{14}$, Kees van der Geest ${ }^{15}$, \\ Claudia M. d. S. Cordovil ${ }^{16}\left(\mathbb{D}\right.$ and Andrej Ficko ${ }^{17}$
}

Citation: Stavi, I.; Paschalidou, A.; Kyriazopoulos, A.P.; Halbac-CotoaraZamfir, R.; Siad, S.M.; Suska-

Malawska, M.; Savic, D.; Roque de Pinho, J.; Thalheimer, L.; Williams, D.S.; et al. Multidimensional Food Security Nexus in Drylands under the Slow Onset Effects of Climate Change. Land 2021, 10, 1350. https://doi.org/ 10.3390/land10121350

Academic Editors: Désirée Gmür, Tobias Haller and Louis Champion

Received: 30 September 2021 Accepted: 3 December 2021 Published: 7 December 2021

Publisher's Note: MDPI stays neutral with regard to jurisdictional claims in published maps and institutional affiliations.

Copyright: (c) 2021 by the authors. Licensee MDPI, Basel, Switzerland. This article is an open access article distributed under the terms and conditions of the Creative Commons Attribution (CC BY) license (https:// creativecommons.org/licenses/by/ $4.0 /)$.
Dead Sea and Arava Science Center, Yotvata 88820, Israel

2 Eilat Campus, Ben-Gurion University of the Negev, Eilat 88100, Israel

3 Department of Forestry and Management of the Environment and Natural Resources, Democritus University of Thrace, 68200 Orestiada, Greece; apascha@fmenr.duth.gr (A.P.); apkyriaz@fmenr.duth.gr (A.P.K.)

4 Department of Civil Engineering, Politehnica University of Timisoara, 300041 Timisoara, Romania; rares.halbac-cotoara-zamfir@upt.ro

5 Department of Environmental Sciences, Informatics and Statistics, Ca' Foscari University of Venice, Via Torino 155, 30170 Venice, Italy; mokrane.siadsi@poliba.it

6 International Centre for Advanced Mediterranean Agronomic Studies (CIHEAM), Mediterranean Agronomic Institute of Bari, Via Ceglie 9, 70010 Valenzano, Italy

7 Department of Environmental Engineering, Polytechnic University of Bari, Via Orabona 4, 70125 Bari, Italy

8 Biological and Chemical Research Centre, Faculty of Biology, University of Warsaw, 00-927 Warsaw, Poland; malma@biol.uw.edu.pl

9 International Platform for Dryland Research and Education, Tottori University, Tottori 680-8550, Japan

10 Faculty of Technology in Leskovac, University of Niš, 18000 Niš, Serbia; savic@junis.ni.ac.rs

11 Instituto Universitário de Lisboa (ISCTE-IUL), Centro de Estudos Internacionais, 2649-026 Lisboa, Portugal; mjflr@iscte-iul.pt

12 Center for Policy Research on Energy and the Environment, Princeton University, Princeton, NJ 08544, USA; lisa.thalheimer@chch.ox.ac.uk

13 Climate Service Center Germany (GERICS), Helmholtz-Zentrum Geesthacht (HZG), 21502 Geesthacht, Germany; david.williams@posteo.net

14 School of Government and Society, The Academic College of Tel Aviv-Yaffo, Yaffo 6818211, Israel; nurithas@mta.ac.il

15 Institute for Environment and Human Security (UNU-EHS), United Nations University, 53113 Bonn, Germany; geest@ehs.unu.edu

16 Centro de Estudos Florestais, Instituto Superior de Agronomia (ISA-UL), Universidade de Lisboa, 1349-017 Lisbon, Portugal; cms@isa.ulisboa.pt

17 Department of Forestry and Renewable Forest Resources, Biotechnical Faculty, University of Ljubljana, 1000 Ljubljana, Slovenia; andrej.ficko@bf.uni-lj.si

* Correspondence: istavi@adssc.org; Tel.: +972-8-6114791

Abstract: Hyperarid, arid, semiarid, and dry subhumid areas cover approximately $41 \%$ of the global land area. The human population in drylands, currently estimated at 2.7 billion, faces limited access to sufficient, affordable, and nutritious food. We discuss the interlinkages among water security, environmental security, energy security, economic security, health security, and food security governance, and how they affect food security in drylands. Reliable and adequate water supply, and the prevention of water contamination, increase the potential for ample food, fodder, and fiber production. Protecting woodlands and rangelands increases food security by buffering the slow onset effects of climate change, including biodiversity loss, desertification, salinization, and land degradation. The protection of natural lands is expected to decrease environmental contamination, and simultaneously, reduce the transfer of diseases from wildlife to humans. Biofuel production and hydroelectric power plants increase energy security but generate land-use conflicts, deforestation, and ecosystem degradation. Economic security generally positively correlates with food security. However, economic growth often degrades the environment, changes tenure rights over natural resources, and stimulates migration to urban areas, resulting in lower food and health security. Moreover, civil unrest, political instability, and armed conflicts disrupt local economies in drylands. 
Maintaining food security is crucial for health security; conversely, malnourished populations and unresponsive health systems decrease economic security, and adversely affect environmental, energy, and food security. Climate change is expected to deteriorate health security by spreading vector-borne diseases. Effective governance and timely interventions can substantially shorten periods of food insecurity, lower their intensities, and accelerate recovery from inevitable crises, and are therefore crucial in preventing humanitarian crises. Since global drylands population will nearly double by 2050 , and since drylands are among the most susceptible areas to climate change, integrated multi-hazard approaches to food security are needed.

Keywords: climatic change; land-use and management; loss and damage; natural vs. anthropogenic factors; population growth and urbanization; slow onset events

\section{Introduction}

Drylands, including hyperarid, arid, semiarid, and dry subhumid areas, cover approximately $41 \%$ of the global land area [1]; the greatest coverage is in low-income countries [2]. Drylands exist in all continents and are inhabited by approximately $40 \%$ of the globe's population, encompassing 2.7 billion people, a number that is expected to increase by up to $50 \%$ by 2050 [3], mostly in the African and Asian drylands. Many people in these countries live in poverty, often subsisting on less than 1 USD a day. Rural populations in these areas, including nomadic, transhumant, and sedentary smallholder agricultural populations, live in increasing insecurity due to land degradation, coupled with a decrease in per capita land due to population growth [4]. Coupled with land tenure changes, land degradation across the world's drylands has been mainly attributed to land misuse, specifically deforestation, excessive fuelwood collection, agricultural malpractices, overgrazing, mining, industrialization, and urbanization. These processes have also contributed to secondary salinization, biodiversity loss, natural resources pollution, and a subsequent decline of related ecosystem services [5].

Simultaneously, climate change has considerably modified natural and anthropogenic systems. Among other effects, one of the most pronounced is the increased fluctuations of precipitation regimes and the longer duration and higher magnitude of droughts, leading to drying of extensive areas across the world [6]. Alongside other meteorological and climatic conditions [7], extremely wet episodes, with high-magnitude rainstorms and devastating floods, are known to accelerate soil erosion and land degradation processes [8]. Additionally, such wet spells have been reported to trigger locust infestation, with the consequent lowering crop yields and food security [9].

In 2011, the concept of slow onset effects (also named slow onset events) was launched as a deliverable at the seventeenth session of the Conference of the Parties (COP 17) on loss and damage, in order to more precisely classify the effects of climatic change. These include increasing temperatures, sea level rise, ocean acidification, glacial retreat, salinization, land and forest degradation, loss of biodiversity, and desertification [10]. The abovementioned processes weaken food security in the world's drylands, where most of the population is already poor and relies on subsistence agriculture and livestock husbandry [11]. Specifically, these processes have adverse impacts on all four pillars of food security, i.e., availability, access, utilization, and stability [12].

Switching to climate-resilient management systems may offer a sustainable path to alleviate food insecurity and poverty in drylands. Although some single-dimensional efforts have been made, the nexus of different dimensions involved in food security highlights the need for a holistic approach to sustainable development of drylands for ensuring safe livelihood [4]. The nexus concept emphasizes the context-specific critical interlinkages across resources, particularly synergies and trade-offs, in a more integrated manner. The perspective used in the nexus' concept is that critical interlinkages may occur between sectors or within sectors of the system that governs food security [13-15]. However, 
a comprehensive analysis of the entire multidimensional nexus of food security's related aspects is still needed. This review study discusses these multiple linkages, focusing on water security, environmental security, energy security, economic security, health security, and food security governance. It outlines and maps key interactions among them and illustrates how slow onset events of climate change affect these interactions.

\section{Water Security}

The availability and accessibility of clean freshwater are particularly critical in drylands, where it is a key life-limiting factor. Water security encompasses the reliable access to a sufficient quantity and quality of water to ensure a healthy lifestyle [16]. Conversely, water insecurity relates to the state of unsustainable, nonreliable, insufficient, contaminated [17], or saline water [18], which does not meet the necessary standards for use by humans. Extreme climatic events, especially long-term droughts and unpredictable precipitation regimes, aggravate water insecurity and accelerate land degradation and desertification [19]. In high mountainous dryland regions, such as Central Asian countries, increasing temperatures over the long-run have led to accelerated retreat of glaciers, simultaneously threatening water and food security for rural populations who rely on the melting water for irrigation of vegetable and fruit tree crops [20]. Across the Mediterranean Basin, recurrent drought episodes increase the severity of water scarcity. Managing decreased water resources becomes particularly challenging when associated with other pressures, such as population growth and higher agricultural demand. The imbalanced distribution of water resources among the different users often leads to disputes, tensions, and violence [21].

Water scarcity is self-evidently the most important factor that limits food production in drylands. Practically, water security directly influences food security by regulating net primary productivity, crop yields, and forage production, thus influencing availability of food for humans [16] and fodder for livestock. Simultaneously, food production affects water security by increasing irrigation demands for crops, and water demands for livestock [22]. Thus, water security and water-use efficiency (also named water productivity) are both key factors with potentially significant impacts on food security [23]. Further, agricultural or livestock-derived wastewater considerably lowers the quality of surface water and groundwater [17]. Moreover, when pumping water from nonrenewable or slow-recharge underground aquifers, their level declines over time, causing consequent harm for long-run agricultural production [24]. Regardless, mismanagement of irrigation water may cause secondary salinization and sodification of extensive lands, resulting in land degradation and desertification, and decreasing crop yields [25]. Another aspect is the use of large quantities of fresh water for food processing and preparation activities, further straining drylands' limited water resources [26].

Water security is a bidirectional variable: it affects and is affected by environmentalsecurity-related issues. For example, water allocation for human needs, involves a trade-off for water allocation for natural ecosystems. Moreover, water contamination adversely affects both environmental and human health [27]. Water security also interrelates with energy security, as hydroelectric discharge converts energy to electricity. Hydroelectric power plants produce clean energy, and simultaneously improve reliability of water provision for human needs [28]. However, flooding of extensive areas upstream of hydroelectric dams inundates natural habitats, may demolish ecosystems, and degrades extensive lands. Simultaneously, these plants considerably change the downstream flow, degrading water quality and harming flora and fauna, sharply decreasing biodiversity [29]. Moreover, dam construction affects human rural populations by uprooting them, degrading their living conditions, decreasing their socioeconomic status, and lowering their access to food [30].

\section{Environmental Security}

Environmental security aims at protecting the environment from risks predominantly caused by anthropogenic factors such as accidents, mismanagement, inappropriate design, 
or ignorance. The key elements of environmental security include preventing natural and anthropogenic damage to the environment, and restoring damages to support human, material, and natural resources at multiple levels, ranging from local to global [31]. Preventing environmental pollution is particularly important. Whether caused by agrochemicals, municipal and industrial sewage sludges, livestock manure (including traces of antibiotics and other medications), or other sources, the implications are adverse for human health and necessitate the restoration of contaminated sites and resources [32].

Land-use change and deforestation for establishing new croplands and grazing lands have led to biodiversity loss, accelerated soil erosion, depletion of soil organic carbon pools, secondary salinization, pollution, eutrophication of water sources, and the overall degradation of soil functions and ecosystem services. Consequently, the potential productive capacity of extensive lands has diminished, lowering agricultural yields and forage production [33], and exacerbating food insecurity. Furthermore, land-use change is responsible for approximately $22 \%$ of the global emissions of greenhouse gases (GHGs); $13 \%$ of the total GHGs are emitted from newly converted lands. Of these, methane $\left(\mathrm{CH}_{4}\right)$ from enteric fermentation is responsible for over one-third, nitrous oxide $\left(\mathrm{N}_{2} \mathrm{O}\right)$ from manure and synthetic fertilizers is responsible for $15 \%$, and $11 \%$ comes from $\mathrm{CH}_{4}$ emissions from paddy rice cultivation [34]. In turn, the increasing GHG concentrations aggravate climatic changes, where the consequent growing frequency and magnitude of severe droughts and devastating floods further lessens potential agricultural productivity and food security [35]. The world's growing population-mostly in regions that already struggle to feed their populations-further exacerbates these environmental threats [4].

Environmental security issues related with agricultural land-use may have strict impacts on human health, for example, through the enrichment of aboveground and underground water sources with excess agricultural nutrients, herbicides, pesticides, insecticides, and fungicides [36]. Similarly, excess manuring may infect these water sources with pathogenic microorganisms and viruses [37]. The use of these aquatic bodies as a source of drinking water may impose serious health risks to human populations. Specifically, contamination of water sources with nitrogen fertilizers has proved to be carcinogenic, both for children and adults [38]. Further, deforestation and the loss of natural lands are known to facilitate the spread of diseases by transferring pathogens from wildlife to humans. For example, this mechanism was proposed as one of the main factors causing many epidemics such as Ebola, AIDS, SARS, avian influenza, and swine flu, as well as for the recent outbreak of the coronavirus (COVID-19; [39]).

Environmental security has long ago been recognized as an integral part of human security, and an important factor in determining national security [40]. Recent history suggests that climate change and environmental security-related hazards can fuel societal conflicts and political unrest. Violence and instability may, in turn, result in mass outmigration, augmenting environmental threats and food insecurity [11,31].

\section{Energy Security}

Energy security has multiple definitions, most of which include the dimensions of energy availability, affordability, capacity, and sustainability [41]. Energy security critically interacts with factors such as climate, water, food, governance, human health, human rights, and national security. Seeking energy security impacts food security in two major ways, i.e., through agriculture's reliance on fossil fuels [42], and the bioenergyfood competition [43]. Industrialized agriculture, which relies on fossil fuels, contributes approximately $10 \%$ to total GHG emissions. Emitted GHGs exacerbate global temperature rise and climatic instability, threatening food production [44]. Simultaneously, land-use changes and pollution associated with extracting, processing, and transporting fossil fuels undermine ecosystem services [45]. Rising demands for food, energy, and their increasingly interlocked markets [46] threaten the global food system as oil supply and agricultural intensification drive food price volatility and food insecurity [42]. 
Contradictions between energy security and other security dimensions may arise. For example, although collection of native woody vegetation for fuelwood alleviates energy insecurity at the household level, it simultaneously accelerates soil erosion, land degradation, and desertification [47]. Similarly, the excessive use of crop residue and livestock manure as fuel depletes soil organic carbon pools and lowers nutrient cycling, degrading the quality and fertility of soils [48]. As a consequence, cropland degradation is accelerated, decreasing agricultural productivity and increasing food insecurity. Further, using these materials for cooking and heating degrades environmental security through the increase in toxic gas emissions and particulate air pollution, and adversely affects health security by causing respiratory-related diseases [49]. Large-scale bioenergy cropping systems, although aimed at energy self-sufficiency and GHG emission mitigation, often compete with food and feed crops for land, water, and fertilizers, aggravating food insecurity and inflating food prices [42,43]. The 2008 global food crisis and ensuing political instability in some parts of the world were partly caused by expansion of the bioenergy industry [46]. This sector also drives environmental insecurity by promoting deforestation for the establishment of bioenergy systems [50], accelerating land degradation and release of GHGs. Some industrialized countries address their own energy security concerns by acquiring large tracts of land for bioenergy cropping in lower-income countries [51], where the already impoverished local communities may lose tenure rights over their lands, be displaced, and face aggravated food insecurity [52]. Yet, certain tracks of the bioenergy sectors-such as pyrolysis of organic waste materials - may be perceived as environmentally friendly, as they are considered carbon-neutral and even carbon-negative processes, while converting wastes into resources. In addition to the production of a flammable gas that can be used as a fuel, pyrolysis coproduces biochar that can be utilized as a soil amendment. It has been shown that applying biochar in soils of croplands [53], rangelands [54], and tree-based systems, such as forestry projects, agroforestry systems, and fruit tree orchards, improves their productive capacity [55], thus increasing economic and food security of local populations.

Other sources of renewable energy can reduce the stresses imposed on either native- or cultured-plant biomass. For example, producing solar energy using photovoltaic panels has become very widespread, particularly in off-grid and remote rural areas [56]. While smalland domestic-scale operations are considered environmentally friendly, the establishment and maintenance of large-scale and commercial solar farms may lead to the degradation of extensive lands, adversely impacting environmental [57] and food security. A possible measure for mitigating these adverse impacts is the subsector of agrivoltaics, which enables the use of the very same lands for photovoltaic panels and agricultural crops [58]. The emerging wind energy sector encompasses another alternative for bioenergy [59]. Yet, serious human rights issues are associated with this sector. For example, private enterprises or corporations - often supported by governments or international firms-dispossess local communities from extensive lands in order to establish large-scale turbine farms. Specifically, across the Global South, this forced land expropriation limits the access of local populations to their communal pasturelands and risks their tenure rights, acquisitions, and possessions. As a consequence, household-level food security is threatened [60]. Further, wind turbines may potentially risk health security. For example, the audible noise and low frequency sound of the turbines' rotating blades were reported to be potentially harmful to human health, and vision problems are occasionally caused by the turbines' shadow flicker [61]. In addition, wind turbines are responsible for fatal bird collisions, causing mass mortality of birds worldwide, thus raising their environmental footprint and further questioning their sustainability [59].

\section{Economic Security}

According to the International Committee of the Red Cross, economic security refers to "the ability of individuals, households or communities to cover their essential needs sustainably and with dignity" [62]. Economic security has direct implications for guaranteeing food security. The livelihoods of many dryland populations rely on natural resources 
that often deteriorate due to harsh climatic conditions and low-fertility soils. Further, many people become food-insecure because of severe political crises or conflicts, which disrupt economic and agricultural activities and contribute to food price shocks and wide economic insecurity [63]. Strictly speaking, these aspects are indirectly linked to food availability. Although sufficient food can be transported to the affected areas, conflicts and political tension still disrupt food supply. For example, in 2017, food prices spiked due to conflict situations in sub-Saharan dryland countries such as Nigeria, South Sudan, and Burundi [64].

Climatic changes pose specific economic security challenges for rural populations in dryland countries, often dependent on rain-fed agriculture as their main source of income [65]. Uncertain rainfalls, long-term droughts, increasing temperatures, and frequent floods adversely affect the ability to produce nutritious and sufficient food [66]. In the Sahel and eastern African drylands, where natural capital and agriculture are the backbone of many economies, agricultural activities and economic security are strongly interconnected [67]. Further, climate change also affects global-scale economic security. For example, in 2011, crop failure in China due to drought led the country to buy wheat on the international market. This caused global wheat prices to increase. Specifically, in Egypt, the world's largest wheat importer, the inflated wheat price tripled bread prices. This triggered a serious economic crisis and caused civil unrest [68].

Regardless, poverty and lack of access to modern markets and infrastructures push local populations towards excessive use of natural resources for energy, accelerating deforestation and clearing of native vegetation from extensive lands [69]. In turn, severe land degradation aggravates the vulnerability of these populations to extreme environmental conditions, which can easily trigger humanitarian crises. For instance, the 2011 east African drought resulted in widespread famine and over 250,000 deaths. In the 2017 drought, fatalities were avoided as a result of the timely and substantial response of the international aid community [70]. By 2030, if temperatures rise by $1.5^{\circ} \mathrm{C}$, it is predicted that an additional 122 million people will experience extreme poverty as a result of increased local, regional, and global food prices [71]. As recurring food crises slow economic growth, effective interventions should aim at simultaneously sustaining food- and economic-security. The current COVID-19 pandemic demonstrates this need [72]. A new composite Proteus Index for measuring the multidimensional concept of food security clearly shows the relations between food security and economic and health dimensions of welfare [73]. Specifically, higher energy and retail prices, alongside reduced incomes due to lockdowns, further coupled with disruption of local markets due to the COVID-19 pandemic, has exacerbated the vulnerability of households in low- and middle-income countries [74].

\section{Health Security}

Climate change impacts on food systems pose risks to human health [75]. For example, resilient immune systems depend on nutritionally adequate diets, both in terms of quantity and quality [76]. A stable provision of nutritious food is essential for human health and vitality. At the same time, those affected by insecure food provision commonly shift to less healthy diets and consume unsafe foods [77]. Undernutrition and food insecurity are key signifiers of a compromised health status, increasing and compounding the risk of chronic disease and poor mental health, particularly in children and adolescents [78]. Further, health hazards associated with extreme weather and climate are increasing globally [75], and cascade with the inputs of systemic risks. For example, the COVID-19 pandemic started as a health crisis, but quickly trickled through socioeconomic, technological, financial, and food systems. Lockdown measures aimed at ensuring health security interrupted global food supply chains, leading to food shortages. While products could not be transported to markets, food was often wasted [79]. Further, COVID-19 is likely to annihilate much of the progress achieved over the last few decades regarding women and children's nutrition. The expected increased numbers of stunted children will compromise their future human capital and economic productivity, further reducing their food security [74]. As climate 
change is likely to increase the frequency of pandemics in the future [80], ensuring access to nutritionally adequate diets should gain a particular urgency in the context of public health [81].

In addition to the health impacts caused by food insecurity, heat exposure is expected to become a serious issue under climate change. The IPCC showed that the increase in annual maximum daytime temperature will affect rural and urban communities, particularly in low- and middle-income countries [82]. Clinical effects of heat exposure include reduced performance and work capacity, strain on cardiovascular systems, heat stroke, morbidity, and mortality [83]. Further health-related impacts from climate-change-related stresses include the geographic expansion of vector-borne pandemics, including malaria, dengue fever, chikungunya, yellow fever, and the Zika virus [82].

Climate change decreases the capacity of health systems to manage the alterations in frequency and intensity of climate-sensitive health outcomes [82]. The impacts of climate change on resilience of health systems vary among countries, as do demographic structures, socioeconomic characteristics, infrastructural effectiveness, and institutional capacities. Specifically, low-income countries that are already disproportionately affected by climate change impacts and are likely to experience more severe impacts to their domestic food systems, face severe exacerbation of existing challenges to health security [75]. Strong adaptation strategies and policies can help reduce the impacts of climate change on human health [44]. Particularly, adaptation schemes should aim at systematically enhancing the capacities of local health systems and communities to adjust, respond, and adapt to increasing climate-related health effects [75].

\section{Food Security Governance}

Governance has been explored in different disciplines as an inclusive perspective at the sociopolitical arena [84]. Examining the interface among water security, environmental security, energy security, economic security, health security, and food security governance highlights the multiple and complex connections among them, with drylands identified as being particularly fragile systems. These interdependencies display the importance of governance as an intermediary agent. Since governance is a normative- and narrativebased concept that strongly focuses on ideal types rather than current practices [85], we suggest defining food security governance as simultaneously ensuring food availability, access, utilization, and stability through effective administration and regulation by multilevel authorities.

Good governance sustains infrastructures and services for wide populations [84]. It also serves as a platform for reconciling conflicting interests related to land-use and utilization of natural resources, for assessing needs, and for more fairly distributing and allocating resources in cases of water scarcity or food shortage [86]. An additional aspect of good governance is allowing more people to participate in decision-making procedures, increasing transparency and strengthening equity [87]. Good governance, whether focusing on practices, solutions, or technologies, is evident in system effectiveness, resulting in shorter periods and lower intensities of food insecurity phases, and faster recovery from crises [86]. Conversely, poor governance contributes to additional losses of food for human consumption [67] and reduces the ability to cope with food crises. These effects are exacerbated in places where land degradation and desertification occur, in which food production is already at risk.

Moreover, it has been demonstrated that poor governance of natural resources may accelerate processes of biodiversity loss, land degradation, and desertification, adversely affecting agricultural productivity and exacerbating food insecurity [88]. For example, in dryland areas of many African countries, it is evident that many public and national infrastructures are unmaintained and deteriorating. Failing public electricity systems encourage the widespread use of coal-fed cookstoves in many lower-income countries, simultaneously leading to deforestation of extensive lands and deterioration of public health [89]. The increasing demand for energy may provide new and more sustainable 
opportunities. The consensus is that governance is needed for lessening the population's reliance on coal and wood for domestic use [90], and for redirecting investors towards renewable energy generation. Therefore, effective governance is a key point for sustaining vulnerable communities and leveraging their livelihood. Further, a holistic governance approach makes it possible to address the multiple aspects of food security. Specifically, proactive governance should promote science and technology solutions, which can play an important role in coping with the different dimensions of food security [91]. One way or another, while promoting technological, infrastructural, and legislative solutions, governance must also include local communities' traditional knowledge, concerns, and needs, as they are inherent to human rights, social stability, and national security.

\section{Synthesis}

Climate change is increasingly degrading dryland resilience and the ability to secure food. Increasingly widespread, frequent, and severe droughts substantially impact the availability, access, and stability of food, and particularly, the regularity and sufficiency of food production [75]. Also, climate change disproportionally harms the health security of already vulnerable and economically or socially disadvantaged people [92]. Anthropogenic activities coupled with human demographic growth exacerbate the pressures imposed on the already fragile drylands, further aggravating food insecurity [4]. The World Food Programme's global hunger monitoring system is an effective tool in assessing the real-time distribution, magnitude, and severity of hunger [93].

The slow onset effects/events of climate change-including increasing temperatures, (terrestrial) glacial retreat, (secondary) salinization, land and forest degradation, loss of biodiversity, and desertification - pose a threat to food security, especially in drylands [11]. Further, in the era of climate change, crops and livestock become susceptible to increased infestation by pests and diseases [94]. Recent assessments indicate that processes of land degradation and desertification, environmental deterioration, and desertification threaten two billion people living in South Asia, East Asia, North Africa, and the Middle East [95].

To combat the problem of hunger and malnutrition in drylands, the security of multiple related dimensions that are critical to human welfare, including water, environment, energy, economy, and health, must be substantially improved, along with their effective governance. For example, adequate water supply and protection of water sources is expected to increase the potential for sufficient food, fodder, and fiber production. At the same time, accelerated land grabbing for bioenergy crops is expected to decrease environmental security due to deforestation and land degradation, simultaneously forcing food production systems into less suitable areas [43]. Similarly, hydroelectric power plants, while expected to increase energy security and thus improve the overall standard of living, generate land-use conflicts and deforestation, and degrade ecosystems and water flow regimes upstream and downstream of the power plant [29]. One way or another, the complex relations between food, energy, and environmental security present policy makers and communities with a 'food, energy, and environment trilemma' [96]. Solving it requires transdisciplinary research, integrated solutions, market regulations, and effective governance. Dryland forests, as well as other high-valued natural or seminatural lands, are key natural resources for sustaining biodiversity and for preventing land degradation, secondary salinization, and desertification. Conservation of such natural resources must become the forefront of the food security agenda [95].

Generally, economic security positively correlates with food security [72]. However, economic growth in lower-income countries often degrades the environment, changes tenure rights over natural resources, and prompts migration to urban areas [97]. Urbanization decreases food self-sufficiency and increases household expenditures for food. In turn, it results in greater dependency on imported food aids under prolonged periods of food shortage [70]. Further, associated issues of rapid urbanization—such as lack of sanitation, poor sewage systems, and elevated air pollution-exacerbate health problems [98]. Specifically, the interrelations among poverty, environmental degradation, and health issues 
have been widely acknowledged $[47,49]$. In the United States, it was recently reported that long exposure to air pollution increases the severity of COVID-19 health outcomes, consequently increasing mortality rates [99].

Vegetation clearing and deforestation may increase the spread of vector-borne diseases from wildlife to humans [39]. The onset of pandemics adversely affects economic activities at all levels, with the most substantial impact in developing countries, in which economies suffer high fiscal vulnerability, and where poverty and inequality are widespread [100]. Eventually, the consequent social unrest, political instability, and armed conflicts encompass a disruptive factor of these economies [64]. Figure 1 illustrates the interrelations among food security, its embedded dimensions, and the slow onset effects under the context of climate change.

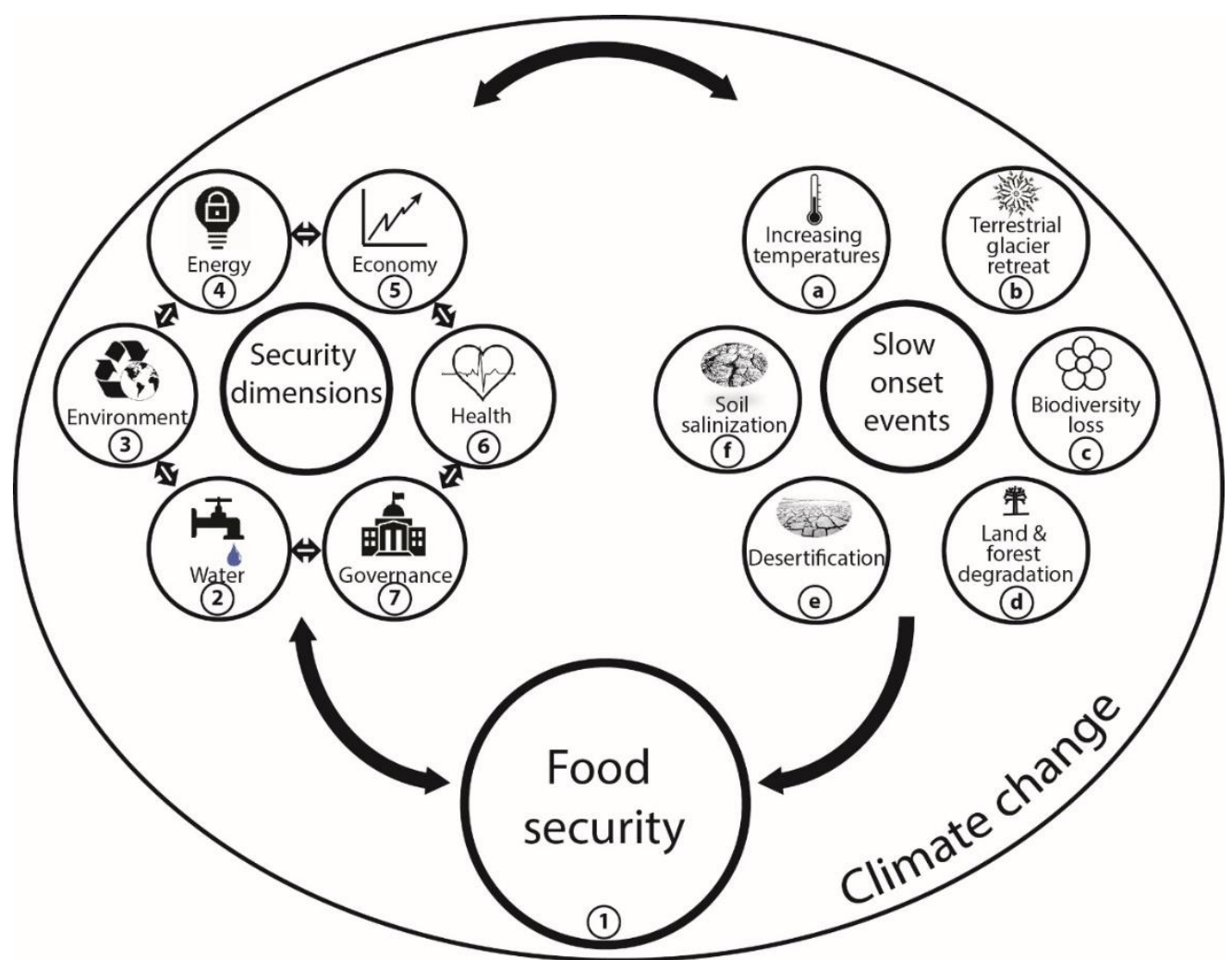

Figure 1. Interrelations among the factors affecting food security under climate change scenarios in drylands. Food security (1), which is strongly dependent on climate change, is interrelated with several dimensions, including water (2), environment (3), energy (4), economy (5), health (6), and their effective governance (7). These dimensions interact with each other, affect food security directly or indirectly, and are impacted by it. The slow onset effects/events (SOEs) -including increasing temperatures (a), (terrestrial) glacial retreat (b), biodiversity loss (c), land and forest degradation (d), desertification (e), and (secondary) salinization (f) —adversely affect food security and its dimensions. In turn, food security and its dimensions adversely affect these events.

What steps should be taken to promote food security in drylands? To sustain drylands, strengthen the livelihoods of their populations, and prevent a global food supply crisis in the future, an effective governance framework is needed that simultaneously deals with the nexus of several dimensions of food security $[4,101]$. First, securing land tenure rights for local communities is expected to strengthen local food production, and improve the status of human rights [102]. Second, preventing malnutrition is crucial for health security [77,78], whereas malnourished populations and unresponsive health systems decrease economic security [74,79], adversely affecting environmental, energy, and food security $[69,70]$. Effective food security governance is expected to shorten the periods of hunger, lower their 
intensities, and enable faster recovery from inevitable crises [86]. Third, for a long-term impact, efforts should be spent to prevent environmental degradation and the irreversible effects of slow onset events of climate change. To date, insufficient emphasis has been given to forecast possible complex effects of the slow onset events, leading to underestimation of potential risks [19]. Achieving proactive and holistic food security is needed; bridging between climate scientists, economists, impact modelers, and decision-makers will promote effective responses to the changing environment. Fourth, governments must accept the fact that humanitarian crises will inevitably result from the slow onset effects of climate change, and that merely depending on international food aid will not suffice to mitigate massive pressures on natural resources in drylands [11]. Ultimately, resource scarcity caused by land misuse and climate change can often lead to violent conflicts, and in some cases, to massive waves of outmigration [64]. These risks could be lowered by designing policy instruments that consider food security as a multidimensional nexus, where water, environmental, energy, economic, and health security, as well as effective food governance are all interconnected and simultaneously treated.

Author Contributions: All authors made a significant contribution to the present manuscript preparation. All authors have read and agreed to the published version of the manuscript.

Funding: This research received no external funding.

Institutional Review Board Statement: Not applicable.

Informed Consent Statement: Informed concept was obtained from all participants of this study prior to their involvement.

Data Availability Statement: Not applicable.

Acknowledgments: This paper was made possible thanks to the framework provided by EU COST Action 16233: 'Drylands Facing Change: Interdisciplinary Research on Climate Change, Food Insecurity, Political Instability'. The Dead Sea and Arava Science Center is supported by the Israel Ministry of Science and Technology. The authors gratefully acknowledge Michelle Finzi for proofreading of the manuscript. Further, the authors thank three anonymous reviewers, whose comments allowed the substantial improvement of the manuscript's original version.

Conflicts of Interest: The authors declare no conflict of interest.

\section{References}

1. Davies, J.; Barchiesi, S.; Ogali, C.J.; Welling, R.; Dalton, J.; Laban, P. Water in Drylands: Adapting to Scarcity through Integrated Management; IUCN: Gland, Switzerland, 2016. Available online: https:/ /www.ecolex.org/details/literature/water-in-drylandsadapting-to-scarcity-through-integrated-management-mon-091227/ (accessed on 29 November 2021).

2. UNEP-WCMC. A Spatial Analysis Approach to the Global Delineation of Dryland Areas of Relevance to the CBD Programme of Work on Dry and Subhumid Lands; UNEP-WCMC: Cambridge, UK, 2007.

3. PBL. Population Growth in Drylands; PBL Netherlands Environmental Assessment Agency: The Hague, The Netherlands, 2017. Available online: http:/ / www.pbl.nl/en/aboutpbl (accessed on 29 November 2021).

4. Stavi, I.; Roque de Pinho, J.; Paschalidou, A.K.; Adamo, S.B.; Galvin, K.; de Sherbinin, A.; Even, T.; Heaviside, C.; van der Geest, K. Food security among dryland pastoralists and agropastoralists: The climate, land-use change, and population dynamics nexus. Anthr. Rev. 2021, in press. [CrossRef]

5. FAO. Land Degradation Assessment in Drylands, Manual for Local Level Assessment of Land Degradation and Sustainable Land Management; Food and Agriculture Organization of the United Nations: Rome, Italy, 2016. Available online: http:/ /www.fao.org/3/i636 1e/i6361e.pdf (accessed on 29 November 2021).

6. Carrão, H.; Naumann, G.; Barbosa, P. Climate Change Impacts on Droughts; European Union: Brussels, Belgium, 2016.

7. Stavi, I.; Perevolotsky, A.; Avni, Y. Effects of gully formation and headcut retreat on primary production in an arid rangeland: Natural desertification in action. J. Arid Environ. 2010, 74, 221-228. [CrossRef]

8. Mullan, D.; Matthews, T.; Vandaele, K.; Barr, I.D.; Swindles, G.T.; Meneely, J.; Boardman, J.; Murphy, C. Climate impacts on soil erosion and muddy flooding at 1.5 versus $2{ }^{\circ} \mathrm{C}$ warming. Land Degrad. Dev. 2019, 30, 94-108. [CrossRef]

9. FAO. Weather and Desert Locust; Food and Agriculture Organization of the United Nations: Rome, Italy, 2016. Available online: http:/ / www.fao.org/3/i6152en/i6152en.pdf (accessed on 29 November 2021).

10. UN-FCCC. Slow Onset Events-Technical Paper; United Nations Framework Convention on Climate Change: Bonn, Germany, 2012. Available online: https:/ /unfccc.int/resource/docs/2012/tp/07.pdf (accessed on 29 November 2021). 
11. UN. The Slow Onset Effects of Climate Change and Human Rights Protection for Cross-Border Migrants. Annual Report of the United Nations High Commissioner for Human Rights and Reports of the Office of the High Commissioner and the Secretary-General; United Nations Human Rights Council: Geneva, Switzerland, 2018. Available online: https://disasterdisplacement.org/portfolio-item/ slow-onset (accessed on 29 November 2021).

12. FAO. An Introduction to the Basic Concepts of Food Security; Food and Agriculture Organization of the United Nations: Rome, Italy, 2008. Available online: http:/ / www.fao.org/docrep/013/al936e/al936e00.pdf (accessed on 29 November 2021).

13. Bleischwitz, R.; Spataru, C.; Vandeveer, S.D.; Obersteiner, M.; Van Der Voet, E.; Johnson, C.; Andrews-Speed, P.; Boersma, T.; Hoff, H.; Van Vuuren, D.P. Resource nexus perspectives towards the United Nations sustainable development goals. Nat. Sustain. 2018, 1,737-743. [CrossRef]

14. Saif, Y.; Almansoori, A. An optimization framework for the climate, land, energy, and water (CLEWs) nexus by a discrete optimization model. Energy Procedia 2017, 105, 3232-3238. [CrossRef]

15. Zhang, J.; Yang, Y.C.E.; Li, H.; Shittu, E. Examining the Food-Energy-Water-Environment Nexus in Transboundary River Basins through a Human Dimension Lens: Columbia River Basin. J. Water Resour. Plan. Manag. 2021, 147, 05021019. [CrossRef]

16. Lall, U.; Davis, J.; Scott, C.; Merz, B.; Lundqvist, J. Pursuing water security. Water Secur. 2017, 1, 1-2. [CrossRef]

17. Sharma, S.; Bhattacharya, A. Drinking water contamination and treatment techniques. Appl. Water Sci. 2017, 7, 1043-1067. [CrossRef]

18. Benneyworth, L.; Gilligan, J.; Ayers, J.C.; Goodbred, S.; George, G.; Carrico, A.; Karim, M.d.R.; Akter, F.; Fry, D.; Donato, K.; et al. Drinking water insecurity: Water quality and access in coastal south-western Bangladesh. Int. J. Environ. Health Res. 2016, 26, 508-524. [CrossRef] [PubMed]

19. Zscheischler, J.; Westra, S.; Van Den Hurk, B.J.J.M.; Seneviratne, S.I.; Ward, P.J.; Pitman, A.; Kouchak, A.; Bresch, D.N.; Leonard, M.; Wahl, T.; et al. Future climate risk from compound events. Nat. Clim. Chang. 2018, 8, 469-477. [CrossRef]

20. Muccione, V.; Huggel, C.; Salzmann, N.; Fiddes, J.; Nussbaumer, S.; Novikov, V.; Hughes, G. Climate-Cryosphere-Water NexusCentral Asia Outlook; Swiss Agency for Development and Cooperation: Bern, Switzerland, 2018. Available online: https: / / zoinet.org/product/climate-cryosphere-water-nexus-central-asia-outlook/ (accessed on 29 November 2021).

21. Iglesias, I.; Garrote, L.; Flores, F.; Moneo, M. Challenges to manage the risk of water scarcity and climate change in the Mediterranean. Water Resour. Manag. 2007, 21, 775-788. [CrossRef]

22. Gerbens-Leenes, P.W.; Mekonnen, M.M.; Hoekstra, A.Y. The water footprint of poultry, pork and beef: A comparative study in different countries and production systems. Water Resour. Ind. 2013, 1-2, 25-36. [CrossRef]

23. Maroufpoor, S.; Bozorg-Haddad, O.; Maroufpoor, E.; Gerbens-Leenes, P.W.; Loáiciga, H.A.; Savic, D.; Singh, V.P. Optimal virtual water flows for improved food security in water-scarce countries. Sci. Rep. 2021, 11, 21027. [CrossRef] [PubMed]

24. De Graaf, I.E.M.; Gleeson, T.; van Beek, L.P.H.; Sutanudjaja, E.H.; Bierkens, M.F.P. Environmental flow limits to global groundwater pumping. Nature 2019, 574, 90-108. [CrossRef] [PubMed]

25. Stavi, I.; Thevs, N.; Priori, S. Soil salinity and sodicity in drylands: A review of causes, effects, monitoring, and restoration measures. Front. Environ. Sci. 2021, 9, 712831. [CrossRef]

26. Vilakazi, N.; Nyirenda, K.; Vellemu, E. Unlocking Water Issues Towards Food Security in Africa, Food Security in Africa, Barakat Mahmoud. Food Secur. Afr. 2019. [CrossRef]

27. Schwarzenbach, R.P.; Egli, T.; Hofstetter, T.B.; von Gunten, U.; Wehrli, B. Global water pollution and human health. Annu. Rev. Environ. Resour. 2010, 35, 109-136. [CrossRef]

28. Herath, I.; Deurer, M.; Horne, D.; Singh, R.; Clothier, B. The water footprint of hydroelectricity: A methodological comparison from a case study in New Zealand. J. Clean. Prod. 2011, 19, 1582-1589. [CrossRef]

29. McCartney, M.P.; Sullivan, C.; Acreman, M.C. Ecosystem Impacts of Large Dams-Background Paper Nr. 2 Prepared for IUCN/UNEP/WCD; United Nations Environment Programme: Nairobi, Kenya, 2001. Available online: https:/ / www.researchgate. net/publication/45165880_Ecosystem_Impacts_of_Large_Dams (accessed on 29 November 2021).

30. De Faria, F.A.M.; Davis, A.; Severnini, E.; Jaramillo, P. The local socio-economic impacts of large hydropower plant development in a developing country. Energy Econ. 2017, 67, 533-544. [CrossRef]

31. Ratner, B.D. Environmental Security: Dimensions and Priorities; Scientific and Technical Advisory Panel to the Global Environment Facility: Washington, DC, USA, 2018. Available online: https://www.thegef.org/sites/default/files/publications/52103\%20 STAP\%20Report_WEB.pdf (accessed on 29 November 2021).

32. Ramankutty, N.; Mehrabi, Z.; Waha, K.; Jarvis, L.; Kremen, C.; Herrero, M.; Rieseberg, L.H. Trends in global agricultural land use: Implications for environmental health and food security. Annu. Rev. Plant. Biol. 2018, 69, 789-815. [CrossRef]

33. Stavi, I.; Bel, G.; Zaady, E. Soil functions and ecosystem services in conventional, conservation, and integrated agricultural systems. A review. Agron. Sustain. Dev. 2016, 36, 32. [CrossRef]

34. Smith, P.; Bustamante, M.; Ahammad, H.; Clark, H.; Dong., H.; Elsiddig, E.A.; Haberl, H.; Harper, R.; House, J.; Jafari, M.; et al. Agriculture, forestry and other land use (AFOLU). In Climate Change 2014: Mitigation of Climate Change. Contribution of Working Group III to the Fifth Assessment Report of the Intergovernmental Panel on Climate Change; Edenhofer, O., Pichs-Madruga, R., Sokona, Y., Minx, J.C., Farahani, E., Kadner, S., Seyboth, K., Adler, A., Baum, I., Brunner, S., et al., Eds.; Cambridge University Press: Cambridge, UK, 2014.

35. FAO. Climate Change and Food Security: Risks and Responses; Food and Agriculture Organization of the United Nations: Rome, Italy, 2015. Available online: https:/ / www.fao.org/3/i5188e/I5188E.pdf (accessed on 29 November 2021). 
36. Mateo-Sagasta, J.; Zadeh, S.M.; Turral, H. Water Pollution from Agriculture: A Global Review-Executive Summary. 2017. Available online: http:/ / www.fao.org/3/i7754e/i7754e.pdf (accessed on 29 November 2021).

37. Ward, M.H.; Jones, R.R.; Brender, J.D.; de Kok, T.M.; Weyer, P.J.; Nolan, B.T.; Villanueva, C.M.; van Breda, S.G. Drinking water nitrate and human health: An updated review. Int. J. Environ. Res. Public Health 2018, 15, 1557. [CrossRef] [PubMed]

38. Ward, M.H. Too much of a good thing? Nitrate from nitrogen fertilizers and cancer. Rev. Environ. Health 2009, $24,357-363$. [CrossRef]

39. WWF. The Loss of Nature and Rise of Pandemics_Protecting Human and Planetary Health; World Wide Fund for Nature: Morges, Switzerland, 2020. Available online: https://d2ouvy59p0dg6k.cloudfront.net/downloads/the_loss_of_nature_and_rise_of_ pandemics__protecting_human_and_planetary_health.pdf (accessed on 29 November 2021).

40. Barbut, M.; Alexander, S. Land degradation as a security threat amplifier: The new global frontline. In Land Restoration-Reclaiming Landscapes for a Sustainable Future; Chabay, I., Frick, M., Helgeson, J., Eds.; Elsevier: Amsterdam, The Netherlands, 2016; pp. 3-12.

41. Azzuni, A.; Breyer, C. Definitions and dimensions of energy security: A literature review. WIRES Energy Environ. 2018,7 , e268. [CrossRef]

42. Karp, A.; Richter, G.M. Meeting the challenge of food and energy security. J. Exp. Bot. 2011, 62, 3263-3271. [CrossRef]

43. Escobar, J.C.; Lora, E.S.; Venturini, O.J.; Yánez, E.E.; Castillo, E.F. Biofuels: Environment, technology and food security. Renew. Sust. Energ. Rev. 2009, 13, 1275-1287. [CrossRef]

44. IPCC. Climate Change and Land, an IPCC Special Report on Climate Change, Desertification, Land Degradation, Sustainable Land Management, Food Security, and Greenhouse Gas Fluxes in Terrestrial Ecosystems; Intergovernmental Panel on Climate Change: Geneva, Switzerland, 2019. Available online: https://www.ipcc.ch/site/assets/uploads/2019/08/Fullreport-1.pdf (accessed on 29 November 2021).

45. Harfoot, M.B.J.; Tittensor, D.P.; Knight, S.; Arnell, A.P.; Blyth, S.; Brooks, S.; Butchart, S.H.M.; Hutton, J.; Jones, M.I.; Kapos, V.; et al. Present and future biodiversity risks from fossil fuel exploitation. Conserv. Lett. 2018, 11, e12448. [CrossRef]

46. Sage, C. The inter-connected challenges for food security from a food regimes perspective: Energy, climate and malconsumption. J. Rural Stud. 2013, 29, 70-80. [CrossRef]

47. Ibrahim, Y.Z.; Balzter, H.; Kaduk, J. Land degradation continues despite greening in the Nigeria-Niger border region. Glob. Ecol. Conserv. 2018, 16, e00505. [CrossRef]

48. Negash, D.; Abegaz, A.; Smith, J.U.; Araya, H.; Gelana, B. Household energy and recycling of nutrients and carbon to the soil in integrated crop-livestock farming systems: A case study in Kumbursa village, Central Highlands of Ethiopia. Glob. Change Biol. Bioenergy 2017, 9, 1588-1601. [CrossRef]

49. Rokoff, L.B.; Koutrakis, P.; Garshick, E.; Karagas, M.R.; Oken, E.; Gold, D.R.; Fleisch, A.F. Wood stove pollution in the developed world: A case to raise awareness among pediatricians. Curr. Probl. Pediatr. Adoles. Health Care 2017, 47, 123-141. [CrossRef] [PubMed]

50. Harvey, M.; Pilgrim, S. The new competition for land: Food, energy, and climate change. Food Policy 2011, 36, S40-S51. [CrossRef]

51. Rulli, M.C.; Savioria, A.; D'Odorico, P. Global land and water grabbing. Proc. Natl. Acad. Sci. USA 2013, 110, 892-897. [CrossRef]

52. Rulli, M.C.; D'Odorico, P. Food appropriation through large scale land acquisitions. Environ. Res. Lett. 2014, 9, 064030. [CrossRef]

53. Laird, D.A.; Fleming, P.; Davis, D.D.; Horton, R.; Wang, B.; Karlen, D.L. Impact of biochar amendments on the quality of a typical Midwestern agricultural soil. Geoderma 2010, 158, 443-449. [CrossRef]

54. Stavi, I. The potential use of biochar in reclaiming degraded rangelands. J. Environ. Plan. Manag. 2012, 55, 657-665. [CrossRef]

55. Stavi, I. Biochar use in forestry and tree-based agro-ecosystems for increasing climate change mitigation and adaptation. Int. J. Sustain. Dev. World Ecol. 2013, 20, 166-181. [CrossRef]

56. Aberilla, J.M.; Gallego-Schmid, A.; Stamford, L.; Azapagic, A. Design and environmental sustainability assessment of small-scale off-grid energy systems for remote rural communities. Appl. Energy 2020, 258, 114004. [CrossRef]

57. Choi, C.S.; Cagle, A.E.; Macknick, J.; Bloom, D.E.; Caplan, J.S.; Ravi, S. Effects of revegetation on soil physical and chemical properties in solar photovoltaic infrastructure. Front. Environ. Sci. 2020, 8, 140. [CrossRef]

58. Ravi, S.; Macknick, J.; Lobell, D.; Field, C.; Ganesan, K.; Jain, R.; Elchinger, M.; Stoltenberg, B. Colocation opportunities for large solar infrastructures and agriculture in drylands. Appl. Energy 2016, 165, 383-392. [CrossRef]

59. Loss, S.R.; Will, T.; Marra, P.P. Estimates of bird collision mortality at wind facilities in the contiguous United States. Biol. Conserv. 2013, 168, 201-209. [CrossRef]

60. Achiba, G.A. Navigating contested winds: Development visions and anti-politics of wind energy in northern Kenya. Land 2019, 8, 7. [CrossRef]

61. CMOH. The Potential Health Impact of Wind Turbines; Chief Medical Officer of Health: Ottawa, ON, Canada, 2010. Available online: https://health.gov.on.ca/en/common/ministry/publications/reports/wind_turbine/wind_turbine.pdf (accessed on 29 November 2021).

62. ICRC. What Is Economic Security? International Committee of the Red Cross: Geneva, Switzerland, 2015. Available online: https:/ / www.icrc.org/en/document/introduction-economic-security (accessed on 29 November 2021).

63. Gaupp, F.; Hall, J.; Hochrainer-Stigler, S.; Dadson, S. Changing risks of simultaneous global breadbasket failure. Nat. Clim. Chang. 2020, 10, 5457. [CrossRef]

64. WFP. 2018 Global Report on Food Crises; World Food Programme: Rome, Italy, 2018. Available online: https://www1.wfp.org/ publications / global-report-food-crises-2018 (accessed on 29 November 2021). 
65. Hallegatte, S.; Rozenberg, J. Climate change through a poverty lens. Nat. Clim. Chang. 2017, 7, 250. [CrossRef]

66. Puma, M.J.; Chon, S.Y.; Kakinuma, K.; Kummu, M.; Muttarak, R.; Seager, R.; Wada, Y. A developing food crisis and potential refugee movements. Nat. Sustain. 2018, 1, 380. [CrossRef]

67. Van der Geest, K.; de Sherbinin, A.; Kienberger, S.; Zommers, Z. The impacts of climate change on ecosystem services and resulting losses and damages to people and society. In Loss and Damage from Climate Change, Climate Risk Management, Policy, and Governance; Mechler, R., Bouwer, L.M., Schinko, T., Surminski, S., Linnerooth-Bayer, J., Eds.; Springer: Berlin, Germany, 2019. [CrossRef]

68. Sternberg, T. Chinese drought, bread and the Arab Spring. Appl. Geogr. 2012, 34, 519-524. [CrossRef]

69. Luna, T.O.; Eguiguren, P.; Guenter, S.; Torres, B.; Dieter, M. What drives household deforestation decisions? Insights from the Ecuadorian lowland rainforests. Forests 2020, 11, 1131. [CrossRef]

70. World Bank. Somalia-Systematic Country Diagnostic; World Bank Group: Washington, DC, USA, 2018. Available online: http:/ / documents.worldbank.org/curated/en/554051534791806400/Somalia-Systematic-Country-Diagnostic (accessed on 29 November 2021).

71. Hoegh-Guldberg, O.; Jacob, D.; Taylor, M. Impacts of $1.5^{\circ} \mathrm{C}$ global warming on natural and human systems. In Global Warming of $1.5^{\circ} \mathrm{C}$. An IPCC Special Report on the Impacts of Global Warming of $1.5^{\circ} \mathrm{C}$ above Pre-Industrial Levels and Related Global Greenhouse Gas Emission Pathways, in the Context of Strengthening the Global Response to the Threat of Climate Change, Sustainable Development, and Efforts to Eradicate Poverty; Masson-Delmotte, V., Ed.; Intergovernmental Panel on Climate Change: Geneva, Switzerland, 2018. Available online: https://www.ipcc.ch/site/assets/uploads/sites/2/2019/02/SR15_Chapter3_Low_Res.pdf (accessed on 29 November 2021).

72. Von Braun, J.; Afsana, K.; Fresco, L.O.; Hassan, M. Food systems: Seven priorities to end hunger and protect the planet. Nature 2021, 597, 28-30. [CrossRef] [PubMed]

73. Caccavale, O.M.; Giuffrida, V. The Proteus composite index: Towards a better metric for global food security. World Dev. 2020, 126, 104709. [CrossRef]

74. World Bank. Responding to the Emerging Food Security Crisis (English); World Bank Group: Washington, DC, USA, 2020. Available online: http:/ / documents.worldbank.org/curated/en/775981606955884100/Responding-to-the-Emerging-Food-Security-Crisis (accessed on 29 November 2021).

75. Schnitter, R.; Berry, P. The climate change, food security and human health nexus in Canada: A framework to protect population health. Int. J. Environ. Res. Public Health 2019, 16, 2531. [CrossRef]

76. Ivers, L.C.; Cullen, K.A.; Freedberg, K.A.; Block, S.; Coates, J.; Webb, P.; Mayer, K. HIV/AIDS, undernutrition, and food insecurity. Clin. Infect. Dis. 2009, 49, 1096-1102. [CrossRef] [PubMed]

77. WHO. Food Safety, Climate Change, and the Role of WHO; World Health Organization: Geneva, Switzerland, 2018. Available online: https://www.who.int/foodsafety/_Climate_Change.pdf (accessed on 29 November 2021).

78. Shankar, P.; Rainjade Chung, B.A.; Frank, M.D. Association of food insecurity with children's behavioral, emotional, and academic outcomes: A systematic review. J. Dev. Behav. Pediatr. 2017, 38, 135-150. [CrossRef] [PubMed]

79. Gaupp, F. Extreme events in a globalized food system. One Earth 2020, 2, 518-521. [CrossRef]

80. Patz, J.A.; Campbell-Lendrum, D.; Holloway, T.; Foley, J.A. Impact of regional climate change on human health. Nature 2005, 438, 310-317. [CrossRef] [PubMed]

81. Kanter, R.; Walls, H.L.; Tak, M.; Roberts, F.; Waage, J. A conceptual framework for understanding the impacts of agriculture and food system policies on nutrition and health. Food Secur. 2015, 7, 767-777. [CrossRef]

82. IPCC. Special Report: Global Warming of $1.5^{\circ} \mathrm{C}$; Intergovernmental Panel on Climate Change: Geneva, Switzerland, 2018. Available online: https://www.ipcc.ch/sr15/ (accessed on 29 November 2021).

83. Kjellstrom, T.; Briggs, D.; Freyberg, C.; Lemke, B.; Otto, M.; Hyatt, O. Heat, human performance, and occupational health: A key issue for the assessment of global climate change impacts. Annu. Rev. Public Health 2016, 37, 97-112. [CrossRef] [PubMed]

84. Hyden, G. Governance and poverty reduction in Africa. Proc. Natl. Acad. Sci. USA 2007, 104, 16751-16756. [CrossRef] [PubMed]

85. Candel, J. Food security governance: A systematic literature review. Food Secur. 2014, 6, 585-601. [CrossRef]

86. Hoon, P.; Hyden, G. Governance and Sustainable Livelihoods. 2003. Available online: https://pdfs.semanticscholar.org/4a6a/b7 fa25713d2b09d316e426aba181345b64f0.pdf (accessed on 29 November 2021).

87. McDermott, M.; Mahanty, S.; Schreckenberg, K. Examining equity: A multidimensional framework for assessing equity in payments for ecosystem services. Environ. Sci. Policy 2013, 33, 416-427. [CrossRef]

88. UNCCD. Land Degradation Neutrality—Resilience at Local, National and Regional Levels; United Nations Convention to Combat Desertification: Bonn, Germany, 2014. Available online: https://www.unccd.int/sites/default/files/relevant-links/2017-08/v2 _201309-unccd-bro_web_final.pdf (accessed on 29 November 2021).

89. Hancock, J.K. The expanding horizon of renewable energy in sub-Saharan Africa: Leading research in the social sciences. Energy Res. Soc. Sci. 2015, 5, 1-8. [CrossRef]

90. Kazimierczuk, A.H. Wind energy in Kenya: A status and policy framework review. Renew. Sust. Energ. Rev. 2019, 107, 434-445. [CrossRef]

91. Darkoh, M.B.K. Environmental security in the drylands of Africa: The role of science and technology. In Human Impact on Environment and Sustainable Development in Africa; Darkoh, M.B.K., Rwomire, A., Eds.; Taylor \& Francis: Abingdon, UK, 2018; pp. 53-73. [CrossRef] 
92. Salas, R.N.; Shultz, J.M.; Solomon, C.G. The climate crisis and Covid-19-A major threat to the pandemic response. N. Engl. J. Med. 2020, 383, e70. [CrossRef]

93. WFP. HungerMapLIVE; World Food Programme: Rome, Italy, 2021. Available online: https://hungermap.wfp.org/ (accessed on 29 November 2021).

94. Garrick, T.A.; Liburd, O.E. Impact of climate change on a key agricultural pest: Thrips. In Environmental Sustainability and Climate Change Adaptation Strategies; Ganpat, W., Isaac, W.A., Eds.; Information Resources Management Association: Hershey, PA, USA, 2018; pp. 232-254.

95. FAO. Trees, Forests and Land Use in Drylands, the First Global Assessment, Preliminary Findings; Food and Agriculture Organization of the United Nations: Rome, Italy, 2016. Available online: http://www.fao.org/3/ca7148en/ca7148en.pdf (accessed on 29 November 2021).

96. Tilman, D.; Socolow, R.; Foley, J.A.; Hill, J.; Larson, E.; Lynd, L.; Pacala, S.; Reilly, J.; Searchinger, T.; Somerville, C.; et al. Beneficial biofuels: The food, energy, and environment trilemma. Science 2009, 325, 270-271. [CrossRef] [PubMed]

97. Ludolph, L.; Šedová, B. Global Food Prices, Local Weather and Migration in Sub-Saharan Africa. 2021. Available online: https:/ / publishup.uni-potsdam.de/frontdoor/index/index/docId/49494 (accessed on 29 November 2021).

98. Yadav, K.; Nikhil, S.V.; Pandav, C.S. Urbanization and health challenges: Need to fast track launch of the national urban health mission. Indian J. Community Med. 2011, 36, 3-7. [PubMed]

99. Wu, X.; Nethery, R.C.; Sabath, M.B.; Braun, D.; Dominici, F. Air pollution and COVID-19 mortality in the United States: Strengths and limitations of an ecological regression analysis. Sci. Adv. 2020, 6, eabd4049. [CrossRef] [PubMed]

100. Mahul, O.; Signer, B. The perfect storm: How to prepare against climate risk and disaster shocks in the time of COVID-19. One Earth 2020, 2, 500-502. [CrossRef] [PubMed]

101. Thalheimer, L.; Williams, D.S.; van der Geest, K.; Otto, F.E.L. Advancing the Evidence Base of Future Warming Impacts on Human Mobility in African Drylands. Earth's Future 2021, 9, e2020EF001958. [CrossRef]

102. Nara, B.B.; Lengoiboni, M.; Zevenbergen, J. Implications of Customary Land Rights Inequalities for Food Security: A Study of Smallholder Farmers in Northwest Ghana. Land 2020, 9, 178. [CrossRef] 